\title{
Kiprah Muhammadiyah dalam Pemberdayaan Masyarakat Desa
}

\author{
Ucin Muksin \\ UIN Sunan Gunung Djati Bandung \\ E-mail: ucin.muksin@gmail.com
}

\begin{abstract}
As a socio-religious organization that has a strong attention to the paradigm of education in the country, Muhammadiyah a mouthpiece for membuminya moral and ethics in society. For Muhammadiyah, education is not only to educate students and the community to be clever, but more importantly how the educational values integrated into the social and religious values. Departing from this fact, this study is directed to look at the lunge, the organization Muhammadiyah in District Bojonggede the "guests" in the community that embraces the philosophy of Ahl al-Sunnah wal-Jama'ah al in an effort to build a people-based education as a form of achievement of civil society (main) in accordance with the vision and mission of Muhammadiyah movement.
\end{abstract}

\section{Kata Kunci:}

Pemberdayaan, pendidikan Islam, civil society

\section{A. Pendahuluan}

Secara struktural, pembangunan yang dikembangkan di wilayah pedesaan tidak sama dengan apa yang dilakukan di daerah perkotaan. Struktur ekonomi pedesaan berada dalam posisi yang tidak menguntungkan dibandingkan dengan struktur ekonomi kota. Struktur ekonomi pedesaan didasarkan pada pertukaran jasa atau pertukaran tenaga kerja, karena kurang tersedianya uang dan tidak adanya kemampuan untuk mengelola uang. Karena tidak tersedianya uang, menyebabkan tenaga kerja digunakan sebagai penggati uang tersebut. Dengan munculnya struktur yang timpang tersebut, terdapat 
kecenderungan untuk lebih menitik beratkan pembangunan pada masyarakat kota. Sebab, hasilnya akan cepat kelihatan, berkat dari adanya sarana yang tersedia, tidak seperti di desa. Kebijakan ini antara lain tercermin pada adanya pusat-pusat pengembangan atau growth centres yang dijadikan pusat-pusat pengembangan ialah kota yang mempunyai penghasilan tinggi. Propinsi Jawa Barat misalnya, menjadikan Bogor sebagai wilayah pengembangan. Akibatnya, banyak wilayah-wilayah yang terlalu jauh letaknya dari pusat-pusat pengembangan tidak atau kurang tersentuh oleh pembangunan. Pembangunan bidang pendidikan misalnya, sampai sekarang ini masih menyisakan berbagai problem mendasar dari hakekat pembangunan pendidikan, sampai pada persoalan sarana pendidikan dan tujuan akhir dari pembangunan pendidikan itu sendiri.

Kecamatan Bojonggede yang termasuk dalam wilayah Kabupatan Bogor merupakan wilayah strategis yang menjadi tempat bagi masyarakat pendatang untuk berdomisili dan tinggal di kecamatan ini. Banyaknya komples perumahan di Kecamatan Bojonggede tidak lain adalah karena wilayah ini berdekatan dengan kota Bogor dan sekaligus berdekatan ke jalur ibu kota Jakarta. Konsekuensi ini secara tidak langsung berdampak pada bertambahnya jumlah penduduk dengan munculnya berbagai persoalan sosio-kultural hingga pada persoalan pendidikan. Banyak usia anak-anak sekolah tidak berada di sekolah, tetapi harus membantu orang tuanya yang sebagian besarnya bekerja sebagai buruh tani.

Organisasi Muhammadiyah sebagai organisasi sosial keagamaan yang mempunyai sense yang kuat terhadap paradigma pendidikan di tanah air menjadi corong untuk membuminya moral dan etik dalam masyarakat. Karena, pendidikan dalam kaca mata Muhammadiyah bukan hanya mendidik anak didik dan masyarakat untuk menjadi pandai, tetapi yang lebih penting bagaimana nilai-nilai pendidikan tersebut terintegrasikan dalam nilai agama dan sosial. Berangkat dari kenyataan inilah, penelitian ini dirahkan untuk melihat sepak terjang, organisasi Muhammadiyah di Kecamatan Bojonggede yang menjadi "tamu" dalam komunitas masyarakat yang menganut falsafah ahl alsunnah wal al-jama'ah dalam usaha membangun pendidikan berbasis 
rakyat sebagai wujud tercapainya masyarakat madani (utama) sesuai dengan visi dan misi gerakan Muhammadiyah.

\section{B. Kerangka Konsep}

Beragamnya persepsi, pemahaman dan pendekatan berbagai kalangan di Indonesia tetang civil society dielaborasi lebih jauh oleh Iwan Gordono Sudjatmiko (2001: 9) bahwa konsep civil society dipahami dikalangan dunia akademis dan aktivis sesuai dengan aksentuasi dan penekannnya masing-masing. Ada kalangan yang memaknai civil society lebih konotasi yang bersifat vertikal. Kalangan ini menerjemahkan civil society menjadi "masyarakat sipil". Bagi mereka, civil society merupakan masyarakat di luar negara yang berperan sebagi kekuatan pengimbang (balancing power) antara negara, individu dan masyarakat pada umumnya. Sebagai konsekuensi dari pemahaman seperti ini, kelompok ini dipengaruhi oleh revolusi "demokrasi" di Eropa Timur yang cenderung menempatkan civil society dalam posisi yang berhadapan, vis-a-vis dengan state. Atau counter hegemoni, bahkan sebagai alternative bagi state. Sementara, sejumlah kalangan ada yang menerjemahkan civil society dengan "masyarakat madani". Menurut Gardono, kelompok yang menerjemahkan civil society sebagai masyarakat madani ini dilandasi secara konseptual dengan konotasi horizontal. Civil society tidak hanya dimaknai seba7gai entitas masyarakat di luar negara (state), tetapi juga dilandasi oleh apa yang disebut Hefner demokrasi keadaban (democratic civility). Konotasi lebih jauh dari pemahaman ini dikaitkan dengan aspek budaya dan merujuk pada warisan sejarah politik Islam pada masa nabi Muhammad di Madinah. Bagi kelompok ini, civil society atau masyarakat madani adalah rumah di mana berbagai asosiasi, perkumpulan, serikat kerja, federasi dan partai politik akan menjadi perisai atau pelindung antara masyarakat dan Negara. Karena itu, dalam masyarakat madani, diperlukan prasyarat-prasyarat kultural yang harus dimiliki dalam entitas masyarakat.

Kendatipun berbagai perdebatan muncul dalam membicangkan lebih jauh tentang civil society secara apologik ada tiga hal yang harus dilihat ketika civil society berhubungan dengan aspirasi negara; pertama 
sebagai komplementer di mana elemen-elemen civil society mempunyai aktivitas memajukan kesejahteraan dengan memajukan kegiatan yang ditujukan untuk melengkapi peran negara sebagai pelayan public (public service). Kedua, sebagai substitutor. Artinya, kalangan civil society melakukan serangkaian aktivitas yang belum atau tidak dilakukan negara dalam kaitannya sebagai institusi yang melayani kepentingan masyarakat luas. Dan ketiga, sebagai kekuatan tandingan negara atau counterbalancing the state atau countervailing forces. Kalangan civil society melakukan advokasi, pendampingan, ligilitas, bahkan praktek-praktek oposisi untuk mengimbangi kekuatan-kekuatan hegemonik negara atau paling tidak menjadi wacana alternatif di luar aparatur birokrasi negara.

Dengan membaca ketiga konsep di atas, kekuatan civil society yang dikembangkan Muhammadiyah dapat dikategorikan pada posisi kedua, dimana melakukan serangkaian kegiatan yang bertujuan sebagai pelayanan publik atau melakukan kegiatan yang belum dilakukan secara maksimal oleh negara. Proses pemberdayaan masyarakat dengan memajukan bidang pendidikan misalnya, dengan tetap berpedoman pada kultur budaya masyarakat merupakan rangkaian yang sinergis dari visi dan mis Muhammadiyah mengembangkan masyarakat di atas tatanan nilai-nilai agama sebagai syarat terbentuknya masyarakat utama (Civil Society) secara meyeluruh.

\section{Pembahasan}

Berdirinya Muhammadiyah di Kecamatan Bojonggede tidak terlepas dari hasil perolehan suara pada pemilu 1999 dimana Partai Amanat Nasional (PAN) memperoleh suara lima ditingkat Nasional, dan tiga besar sesudah Golkar di Kabupaten Bogor. Dengan perolehan suara yang cukup kompetitif tersebut, pengurus Daerah Muhammadiyah yang ada di Kabupaten Bogor secara proaktif melakukan dialog dengan pengurus cabang yang ada untuk melakukan "pembumian" dan sekaligus berusaha memperkuat jaringan keorganisasian dengan pengurus cabang Muhammadiyah lainya dengan mendirikan cabangcabang organisasi Muhammadiyah di kecamatan-kecamatan dalam lingkungan Kabupaten Bogor. 
Berangkat dari hasil musyawarah pengurus daerah dan cabang Muhammadiyah Kabupaten Bogor, maka pada akhir November tahun 1999 atau tepatnya 27 November 1999 terbentuklah pengurus cabang Muhammadiyah di Kecamatan Bojonggede yang berkedudukan di desa Pabuaran. Berkembangnya Muhammadiyah di Kecamatan-Kecamatan yang ada dalam lingkungan Kabupaten Bogor merupakan proses aksi sosial keagamaan yang baru dalam lingkungan masyarakat masyarakat Kabupaten Bogor yang cukup ketat menganut ahl al-sunnah wal aljama'ah-kendatipun tidak ada kepengurusan NU di Kecamatan Bojonggede misalnya- dalam kehidupan keagamaan mereka.

Di bawah bendera kepengurusan Santoso, langkah awal yang dilakukan cabang Muhammadiyah di Kecamatan Bojonggede adalah memperkuat jaringan kepengurusasan Muhammadiyah dengan membuka ranting sebagi basis pergerakan di tingkat massa dalam usaha memperkenalkan dan membumikan Muhammadiyah baik dalam aspek sosial maupun keagamaan. Dengan koordinasi yang terpadu ditingkat cabang dan daerah, dalam Kecamatan Bojonggede sendiri saat ini (sampai penelitian ini dilakukan) telah ada 7 (tujuh) ranting organisasi Muhammadiyah yang terdapat di desa Bojonggede, Kedungwaringin, Rawapanjang, Bojongbaru, Pabuara, Waringijaya dan Citayem.

Berdirinya ranting Muhammadiyah di beberapa desa dalam wilayah Kecamatan Bojonggede, merupakan usaha keras gerakan Muhammadiyah melakukan perubahan-perubahan inkramental dan informatif sebagai wujud memasyarakatkan Muhammadiyah yang berpegang teguh pada nilai-nilai amar makruf nahi mungkar dalam mengembangkan, dan menyumbangkan pemikiran mendapatkan kemurnian dan kebenaran Islam sebagai aras terbentuknya masyarakat Islam.

Dengan berpedoman pada AD/RT keorganisasian Muhammadiyah, cabang Muhammadiyah di Kecamatan Bojonggede, berupaya kuat untuk tetap mengkonsulidasikan struktur keorganisasian baik dari tingkat atas hingga tingkat bawah. Dengan dibantu 35 orang dengan bidang yang ada, keorganisasian Muhammadiyah secara kontiniu, membuka jaringan dan tetap menjalankan misi keorganisasian yang sudah termaktub dalam tugas gerakan Muhammadiyah. Untuk 
mencapai tujuan tersebut, disusunlah beberapa majelis diantaranya, majelis tabliqh dan dakwah, majelis Tarjih dan Pengembangan Pemikiran Islam, majelis Pendidikan Dasar dan Menengah, Majelis Kesehatan dan kesejahteraan Masyarakat, majelis ekonomi, majelis Wakaf dan Kehartabendaan, majelis Pengembangan Kader dan Sumber Daya Insani, serta Biro Pembinaan dan Pengawasan Keuangan, yang dibentuk tidak lain untuk tercapainya tujuan pokok organisasi Muhammadiyah sebagai gerakan pembebasan menuju pada kebenarankebenaran yang terdapat dalam Al-Quran dan Sunnah.

Gerakan Muhammadiyah dalam proses ini berusaha mengimplementasikan sebuah lembaga pendidikan yang integrated yang mampu mengatasi munculnya split orientasi pendidikan. Artinya, Muhammadiyah berusaha semaksimal untuk menyelenggarakan pendidikan yang balance antara jasmani, intelektualitas, pemikiran, dan hal-hal duniawi lainnya dengan rohani, kenyakinan, perasaan dalam bingkai long life education sehingga mampu mewujudkan masyarakat berpendidikan. Hal ini sesuai dengan tujuan pendidikan yang dicanangkan oleh organisasi Muhammadiyah sendiri dimana; 1 . Pendidikan moral harus berorientasi pada penanaman karakter manusia dengan berdasarkan Al-Quran dan Sunnah. 2. Pendidikan individu diarahkan untuk menumbuhkan kesadaran individu yang integrated seimbang atau equilibrium dalam aspek jasmani dan rohani. 3. Pendidikan kemasyarakatan difokuskan untuk menumbuhkan solidaritas sosial sebagai modal hidup bermasyarakat. Ketiga tujuan ini merupakan gerakan pendidikan Muhammadiyah yang berjalan secara kontinui sebagai usaha memberikan pendidikan yang mencerdaskan masyarakat luas. Karenanya, salah satu kritikan yang dialamatkan kepada Muhammadiyah dianggap lembaga elit dan cenderung menjaga jarak dengan masyarakat akar rumput, tidaklah benar. Ini sebagaimana disebutkan Din Syamsuddin, Muhammadiyah bukanlah organisasi perkotaan, tapi ia juga organisasi yang peka dengan masyarakat bawah. Hal ini juga seperti dituturkan Ali Nurdin, tidaklah benar bila ada yang mengatakan organisasi Muhammadiyah hanya sence dengan dengan kelas elit atau menengah, dan tidak memperdulikan kelas bawah. Muhammadiyah yang terbentuk dan didirikan di Kecamatan Bojonggede khususnya, dan Kabupaten Bogor umumnya, selalu melakukan kegiatan 
sosial dan keagamaan yang lebih diperuntukan bagi masyarakat akar rumput, dan malah menurutnya Muhammadiyah telah berbuat banyak untuk pemberdayaan pendidikan masyarakat, dari organisasi sosial lainnya yang ada di Kecamatan Bojonggede.

Salah satu aksi sosial yang dilakukan Muhammadiyah cabang Bojonggede adalah ketika mensikapi perkembangan sekolah yang didirikan oleh yayasan non-muslim khususnya Kristen yang berada dalam komplek perumahan untuk memberi pengajaran dan pendidikan yang komunitas warganya bergama Islam. M. Suhardi menjelaskan, bagaimana warga masyarakat perumahan di komplek Gavery 2 yang ada dalam wilayah Kecamatan Bojonggede tidak dapat membaca, dan juga termasuk tokoh masyarakatnya "kita kecolongan" dimana pada akhir tahun 2003, di komplek Gavery tersebut telah berdiri taman kanak-kanak yang dikelola yayasan HKBP yang berpusat di Kota Bogor. Taman kanak-kanak yang didirikan tersebut saat ini cukup banyak menampung siswa dalam komplek dan masyarakat sekitar komplek yang memasukkan anak-anak mereka ke taman kanak-kanak tersebut. Membaca kondisi ini, pendidikan menjadi prasyarat untuk mensikapi perubahan nilai yang ada dalam masyarakat Bojonggede, karenanya ketika kita juga mendirikan pendidikan taman kanak-kanak di desa Waringin Jaya yang tidak jauh dari perumahan Gavery 2 tidak lain adalah untuk mensikapi persoalan sarana pendidikan yang semakin dibutuhkan oleh masyarakat. Kendati taman kanak-kanak yang baru berjalan \pm 6 bulan, diupayakan semaksimal mungkin memberikan pendidikan yang mampu dijangkau masyarakat luas, dengan memadukan model pendidikan piker dan moral. Tambahnya, sebelumnya taman kanak-kanak yang diberi nama 'Alfiyah" ini cuma diikuti oelh 10 siswa dari warga komplek Gavery 2, tetapi sekarang ini sudah mencapai 35 anak didik yang juga berasal dari warga sekitar komplek perumahan yang dibimbing oleh 7 orang guru.

Demikian juga halnya dengan perkembangan SD Muhammadiyah yang terletak di desa Pabuaran. Lokasi sekolah yang berdiri di atas tanah wakaf seorang pengusaha dari Jakarta, $\pm 1000 \mathrm{M}^{2}$ merupakan SD kedua yang ada dalam wilayah desa Pabuaran dimana sebelumnya sudah ada sekolah dasar. Pendirian, sekolah ini didasari atas persoalan 
sedikitnya daya tampung anak-anak didik yang bersekolah di SD Pabuaran. Kendati pembangunan SD ini memakan waktu yang lama dengan swadana masyarakat dan bantuan dari pihak luar, tahun awal ajaran 1999/2000 jumlah murid hanya 20 orang siswa, tetapi hingga saat ini telah mencapai 250 orang siswa yang tidak hanya berasal dari wilayah Pabuaran, tetapi juga dari sekitar wilayah Pabuaran. Akar pendidikan ala Muhammadiyah tidak terlepas dari falsafah ta'lim, tarbiyah dan ta'lim. Ta'lim berusaha mencerdaskan otak manusia, tarbiyah mendidik perilaku yang benar, sedangkan ta'bib memperhalus adab kesopanan ${ }^{1}$.

Satu sisi yang harus dilihat, bahwa jumlah sekolah lebih kurang 6 pendidikan dasar hingga menengah, aspirasi pendidikan yang dikembangkan dalam sistem pendidikan Muhammadiyah sebagai uapaya memberantas melek huruf dan membantu kebutuhan pendidikan bagi masyarakat kurang mampu. Tingginya uang pendidikan dibeberapa sekolah yang ada di Kecamatan Bojonggede, merupakan pemicu utama dikembangkannya dan dibangunnya beberapa sekolah untuk mencukupi kebutuhan pendidikan bagi masyarakat umumnya.

Di desa Cimanggis misalnya, sekarang ini kita sedang membebaskan perluasan tanah seluas $\pm 6000 \mathrm{M}^{2}$ yang dipergunakan nantinya untuk pembangunan sekolah kejuruan, yang bisa bermanfaat bagi masyarakat. Desa Cimanggis dikembangkan untuk pembangunan sekolah kejuruan, sesuai dengan iklim pekerjaan masyarakat setempat yang sebagiannya bekerja sebagai petani. Artinya, kita mengharapkan nantinya alumni-alumni sekolah kejuruan tersebut dapat mempengatuhi incam dari masyarakat setempat. Dari sistem taman hingga pemanfaatan teknologi pertanian.

Pendidikan yang dikembangkan juga tetap memegang kultur masyarakat Bojonggede, artinya, pendidikan yang dirancang memegang pola pragmatis, praktis, sederhana, dan populis yang bernafaskan agama. Pendidikan yang murah, dan kemudahan sarana dan prasarana merupakan ciri dominan sekolah yang dikembangkan Muhammadiyah.

${ }^{1}$ M. Amin Rais, "Tauhid Sosial : Doktrin Perjuangan Muhammadiyah", dalam media Indonesia, Jurnal Universitas Muhammadiyah, Yogyakarta, No. $1,1996$. 
Dan tidak benar bila ada yang mengatakan bahwa pendidikan di lembaga pendidikan dari SD hingga sekolah menengah atas mahal dan banyak dipungut biaya untuk proses belajar bagi anak didik². Hal ini apa yang diungkapkan bu Elly, kami sangat terbantu dengan berdirinya SMP Muhammadiyah di tempat kami, di desa Kedung waringin. Karena sebelum ada SMP Muhammadiyah, SMP yang ada di sini cuma satu dan agak jauh terjangkau oleh anak-anak, kendatipun sarana transportasi cukup mendukung. Dengan adanya SMP Muhammadiyah di tempat kami, secara tidak langsung telah ikut membantu warga Kedung Waringin, yang ingin menyesekolahkan anaknya ke jenjang yang lebih tinggi dari sekolah dasar. Apalagi bagi saya, yang hanya berpenghasilan sebagai pedagang kecil, apa yang telah dikembangkan Muhammadiyah sekarang ini merupakan usaha yang cukup baik dan sangat bermanfaat bagi masyarakat.

Arah misi pendidikan berbasis rakyat yang tertuang dalam AD/RT (lihat lampiran) secara sinergis berusaha mengimplementasikan pendidikan berdasarkan lima tahapan. Pertama, secara kontiniu terus menyempurnakan materi kurikulum khususnya yang menyangkut penekanan akhlak dan budi pekerti dalam mengantisipasi perubahan global yang muncul dalam laju dan gerak masyarakat Bojonggede, baik ditingkat sekolah dasar hingga menengah. Kedua, berusaha meningkatkan kempuan akademik siswa dalam bentuk pencapain nilainilai rata-rata tujuh untuk memasuki jenjang pendidikan yang lebih tinggi dan menghadapi kompetensi dalam peningkatan prestasi ditengah masyarakat . Ketiga, berupaya meningkatkan rasionalitas para guru persyarikatan dan guru tenaga honorer yang selama ini pada posisi 2 berbanding 8 untuk kemudian diubah menjadi 8 berbanding 2 atau sekurang-kurangnya enam guru persyarikatan berbanding empat guru horoner. Keempat, meningkatkan kesejahteraan guru dan karyawan Muhammadiyah melalui perbaikan sistem pengajaran dengan standard tertentu. Pola ini akan meliputi tunjangan keluarga, tunjangan jabatan, tunjangan kesehatan, tunjangan perumahan, maupun tunjangan pendidikan. Dan terakhir, meningkatkan dan menyempurnakan sarana

\footnotetext{
${ }^{2}$ Wawancara dengan Ali Nurdin, Tanggal 16 Agustus 2004.
} 
dan prasarana pembelajaran siswa sehingga proses belajar mengajar bisa berlangsung secara optimal.

Dengan kelima tahapan ini diharapkan, visi dan misi pendidikan yang diemban gerakan Muhammadiyah mampu memaksimalkan kebutuhan dasar masyarakat dari proses pencerdasan masyarakat secara menyeluruh. "Apa yang telah coba dilakukan dengan kerjasama antar institusi serta ranting yang ada di daerah wilayah Kecamatan Bojonggede, merupakan cita-cita awal dari Muhammadiyah sejak berdiri di Kecamatan Bojonggede". Kami ingin melakukan sesuatu untuk mencerdaskan masyarakat sesuai dengan kebenaran Al-Quran dan Sunnah, dan bukan kebenaran dari guru atau orang "alim" yang malah membelenggu pikiran masyarakat untuk berpikir kritis.

Sebagai organisasi sosial keagamaan sejak berdirinya di Kecamatan Bojonggede, Muhammadiyah yang dapat disebutkan sebagai pendatang baru di dalam komunitas ahl al-sunnah wal al-jama'ah, merupakan organisasi Islam dan dakwah yang secara doktrin bergerak lebih menekankan pada upaya pemberdayaan masyarakat melalui lembaga pendidikan dan sosial kemasyarakatan. Dalam proses perkembangannya Muhammadiyah melakukan gerakan sosial dan keagamaan yang juga tetap berorientasi pada ahl al-sunnah wal aljama'ah, tetapi bukanlah ahl al-sunnah wal al-jama'ah yang dipahami masyarakat atas "keshalehan" seorang kiai atau ikut-ikutan yang tidak dilandasi dari kebenaran nilai-nilai Al-Quran dan Sunnah. Artinya, Muhammadiyah melihat proses pembelajaran (pendidikan agama misalnya) yang berkembang dalam masyarakat Kecamatan Bojonggede bukanlah dimulai dari kebenaran berpikir dan kritis dari sistem kehidupan keagamaan mereka, tetapi yang terlihat adalah proses pembelengguan dan penyempitan cara berpikir dari kebenaran yang tertuang dalam ajaran agama itu sendiri.

Merujuk kepada AD/RT yang tertuang dalam program kerjanya, Muhammadiyah selain melalui jalur pendidikan formal untuk menciptakan masyarakat utama (civil society), juga menggunakan sarana masjid sebagai wadah membentuk pribadi yang mampu mengimplementasikan amar ma'ruf nahi mungkar dalam kehidupan sehari-hari. Pengkajian dan pengajian agama yang dilakukan setiap awal 
bulan atau pada sabtu sore semisal di Masjid Baitul Makmur, yang sering disebut masyarakat base camenya orang-orang "Muhammadiyah", tidak lain berupaya melakukan diskusi dan ceramah agama yang diarahkan pada logika pikir masyarakat untuk berdialog dengan Al-Quran tentang kebenaran sosial dan Ilahi. Dan bahkan setiap sore Jum'at juga diisi dengan pengajian rutin yang membahas masalah ibadah sampai muamalah yang tidak hanya diikuti oleh warga Kedungwaringin, tetapi juga masyarakat sekitar Kedungwaringin. Karena, menurut Damad Rochmadiyono, pengajian ini dilakukan bukan berarti kita ingin mengatakan bahwa apa yang telah dilakukan sebagian masyarakat itu salah, tetapi yang terpenting kita ingin mentransferkan pengetahuan kepada masyarakat kendatipun sebagiannya adalah buruh tani, bagaimana kebenaran agama tidak didasari atas pengetahauan seseorang yang dianggap "sholeh" atau ikut-ikutan, tetapi kebenaran agama adalah bersumber dari kebenaran Al-Quran dan Sunnah. Selain dilakukan di Masjid Baitul Makmur di desa Kedungwaringin, pengajian dan kajian agama juga dilakukan di Masjid komplek perumahan di desa Pabuaran. Di komplek ini kendati komunitas warga Muhammadiyah tidak sebanding dengan di desa Kedungwaringin, namun aktifitas sosial dan keagamaan berjalan lancar. Pengajian yang dilakukan sesudah $b a^{\prime} d a$ ashar tiap jumatnya, tidak hanya diikuti oleh warga dalam komplek, tetapi juga oleh warga luar komplek.[]

\section{Penutup}

Dengan berakar dari tradisi pikir, gerakan Muhammadiyah lebih kental kepada gerakan pemberdayaan masyarakat sebagai akumulasi struktural dan kepincangan kultural dari kepongahan pembangunan. Cita-cita pembangunan yang berkembang saat ini tidak hanya mewujudkan masyarakat adil dan makmur di satu sisi, tetapi di sisi yang lain ideologi pembangunan yang ada sekarang ini, secara sengaja mempertahankan kesejangan sosial dan kemiskinan yang nyata dalam masyarakat.

Untuk mewujudkan visi dan misi Muhammadiyah sebagai gerakan sosial dan keagamaan usaha yang dilakukan adalah dengan melakukan pemberdayaan pendidikan secara menyeluruh dalam 
masyarakat. Pemberdayaan pendidikan yang dilakukan Muhammadiyah di Kecamatan Bojonggede adalah wujud nyata Muhammadiyah mencetak intelektualitas beriman, dan masyarakat belajar yang berusaha berpikir berdasarkan kebenaran ajaran agama Islam dan bukan kebenaran taqlid guru atau dari belenggu ideologi orang-orang "shaleh".

Pemberdayaan pendidikan yang dikembangkan Cabang Muhammadiyah tidak hanya terfokus pada pendirian lembaga pendidikan seperti SD, SMP, MTsN, atau SMU, namun juga proses pencerdasan dan upaya pengamalkan ajaran Islam sesuai Al-Quran dan Sunnah juga dilakukan di Masjid. Kajian di Masjid setiap awal bulan dan pada hari sabtu atau jumat setiap minggunya, disyiarkan bukan berarti sebagai wujud tandingan untuk mengatakan bahwa apa yang telah ada dengan falsafah ahl al-sunnah wal al-jama'ah dilakukan sebagian masyarakat Kecamatan Bojonggede sekarang adalah salah, tapi pengajaran pendidikan yang berpola pada tradisi kritik terhadap pengamalan dan mencari kebenaran agama berdasarkan Al-Quran dan Sunnah dan bukan kebenaran hasil ikut-ikutan, sebagai usaha memperluas pangalaman keagamaan yang mudah dipahami masyarakat pada umumnya dan dan bagi komunitas Muhammadiyah khususnya.[] 


\section{DAFTAR PUSTAKA}

Dewan Redaksi, 1994. Dalam Ensiklopedi Islam, III, Jakarta: Ihctiar Baru Van Hoeve

Engineer, Ashgar Ali, 1996. The Islamic State, New Delhi: Vikas Publising House

Ghozali, Abd. Rohim, 2000. Dua Yang Satu: Muhammadiyah dalam Sorotan Cendikiawan NU, Bandung: Mizan

Hefner, Robert W., 2000. Civil Islam : Islam dan Demokratisasi di Indonesia, Jakarta: ISAI

Hikam, Muhammad AS, 1999. "Islam dan Perkembangan Civil Society di Indonesia", dalam Muhammad AS Hikam, Wacana Politik Hukum dan Demokrasi Indonesia, Yogyakarta: Pustaka Pelajar

1999. Wacana Politik Hukum dan Demokrasi

Indonesia, Yogyakarta: Pustaka Pelajar 1999. Demokrasi dan Civil Society, Jakarta: LP3ES 1999. “Wacana Intelektual Tentang Civil Society di Indonesia, dalam Jurnal Paramadina, Volume 1, Nomor 2

Huntington, Samuel P. 1996. Benturan Antar Peradaban dan Masa Depan Politik Dunia, Yogyakarta: Qalam

1993. "Democracy Third Wave", dalam Larry Diamond and Marc F. Plattner, The Global Resurgence of Democracy, Baltimore and London: John Hopkins University Press

Karim, M. Rusli, 1986. Muhammadiyah Dalam Kritik dan Komentar, Jakarta: Rajawali Press

1999. Negara dan Peminggiran Islam Politik:

Suatu Kajian Mengenai Implikasi Kebijakan Pembangunan Bagi Keberadaan Islam Politik di Indonesia Era 1970-an dan 1980-an, Yogyakarta: Tiara Wacana

Nazir, Mohd., 1985. Metode Penelitian, Jakarta: Ghalia Indonesia

Nucholish Madjid, 1997. Tradisi Islam Peran dan Fungsinya Dalam Pembangunan di Indonesia, Jakarta: Paramadina 
Mulkhan, Abdul Munir, 1995. Teologi Kebudayaan dan demokrasi Modernitas, Yogyakarta : Pustaka Pelajar

Panduan Musyawarah Cabang (Muscab) Muhammadiyah Kecamatan Bojonggede, Kabupaten Bogor, 2001.

Prasetyo, Hendro, 2002. Islam dan Civil Society, Jakarta: Gramedia Pustaka Utama

Raharjo, M. Dawam, 1998. Masyarakat Madani : Agama, Kelas Menengah, dan Perubahan Sosial, Jakarta: Paramadina

Rais, M. Amin, 1996. "Tauhid Sosial: Doktrin Perjuangan Muhammadiyah", dalam media Indonesia, Jurnal Universitas Muhammadiyah, Yogyakarta, No. 1, 1996.

Seligman, Adam B., 1998. The Idea of Civil Society, New York, The Free Press

Ubaidillah, A., 2000. Pendidikan Kewargaan: Demokrasi, HAM, dan Masyarakat Madani, Jakarta: IAIN Jakarta Press 